DOI https://doi.org/10.18551/rjoas.2017-12.08

\title{
MEDIATION EARNING PER SHARE IN INFLUENCING THE RELATIONSHIP BETWEEN FINANCIAL RATIOS, COMPANY SIZE AND OPERATING CASH FLOW TO STOCK RETURN
}

\author{
Wijaya Eka Chandra* \\ Student Master Degree of Economy and Business, \\ University of Brawijaya, Indonesia \\ Ludigdo Unti, Rachman Aulia Fuad \\ Department of Accounting, Faculty of Economy and Business, \\ University of Brawijaya, Indonesia \\ *E-mail: ekachandra ak@yahoo.co.id
}

\begin{abstract}
This research focuses on examining the influence of financial ratios using several variables (net profit margin, return on equity, debt to equity ratio, current ratio, price to book value, total asset turnover), firm size and operating cash flow to stock return through mediation earning per share in manufacturing companies. This research uses the financial statements of manufacturing companies for 7 years (2008-2014) with purposive sampling method and obtained 38 samples of manufacturing companies. This research is classified as a quantitative research with analytical method used is path analysis. The results of this research indicate that net profit margin, total asset turnover, debt to equity ratio, and firm size directly affect the variable earnings per share. While the results of path analysis explained that earnings per share indirectly mediate the relationship between net profit margin, total asset turnover, debt equity ratio, and firm size to stock return variables.
\end{abstract}

\section{KEY WORDS}

Financial ratios, company size, operating cash flow, stock return, path analysis.

Research conducted by Riegel (2013) in his book entitled Stock for the Long Run investigated real return on all types of investment activities from 1802 to 2012 in the United States and Britain. The results of this research published in the Journal of Monetary Economic show that stock investment is the most profitable investment activity compared to other investments such as bonds, gold and foreign exchange, both long-term investment and short-term investment.

Stock prices tend to be more stable towards the economic inflation rate so that trading in the stock market becomes quite crowded. The ease of obtaining information increasingly causing investors interested in investing and trading stocks. Undeniably the stock return is also influenced by other components such as earnings, interest rate, risk and the uncertainty of psychological factors of an investor (Riegel, 2013).

Bhattacharya (1979) developed a signal model, that the high dividends distributed indicate the high performance of the company that will increase the company's value and the company's stock price. Furthermore, the signal model was developed by Rozeff (1982) into signaling theory hyphotesis which assumes that the dividend seems to have information or as a cue to the future prospects of the company, so it can be concluded that the signaling theory is emphazising more on how important information issued by a company and its effect on the prospects and future of the company.

Information is a very important element for both investors and business actors i.e. description of the condition of the company, both past conditions, current and future circumstances to see the viability of a company. Therefore, complete, relevant, accurate and timely information will be necessary for investors in investing in the capital market as an analytical tool in deciding investment through earning per share viewed based on net income 
of the company and will ultimately affect the profit of investors in the market Capital through stock returns.

Alexander et al. (1993) stated that the announcement of accounting information can represent that the company has a good prospect in the future or a portrait for investors so that investors are interested in trading stocks, thus the market will react as reflected through changes in stock trading volume. Therefore the relationship between the publication of information whether the financial statements, financial or socio-political conditions to fluctuations in trading volume of shares can be seen in market efficiency. The information in this research is the annual financial statements of companies that are analyzed using financial ratios. According to Van Horne and John (2005) the analysis and interpretation of the various ratios can provide a better view of the financial condition and achievement of the company than the financial data is not shaped ratio, so the results of the ratio calculation is expected to provide an insight for investors in investing.

Theoretical framework in this research explains the influence of financial information issued by the company is able to provide an insight for investors in gainining profits in the market efficiently through stock returns. Huda and Nasution (2008) explained that investors are using financial statement information by looking at various factors that can affect the rate of return. This forms as a fundamental factor that the value of a company's stock is reflected in the company's financial performance. Companies that publish annual report information with good performance are expected to provide an insight and can provide maximum profit for investors in the market efficiently through stock returns.

Stock returns are heavily influenced by many factors other than the company's annual information, such as the characteristics of the company. The characteristics of a company are assumed to have a major influence on investor decisions related to the profit to be gained. Characteristics of companies in this research includes the firm size, where one of these characteristics is widely used as a research variable in affecting stock return associated with risk and return obtained by investors.

Panjaitan (2004) argued that firms with small-scale or limited assets tend to be less profitable for investors to invest compared to large-scale companies or large assets. This is because small-scale companies have supporting factors to produce goods in limited quantities compared to large companies. So based on the explanation can be concluded that companies with small scale tend to have a relatively high risk compared with large-scale companies.

Another supporting parameter in the financial statements that can be used as a reference for investors in investing is the company is cash flow. Most of the company's earnings are influenced by the activities contained in the cash flows, especially cash flows from operating activities that are the main operating activities of the company. Statement of financial accounting standards that describes the cash flows of the company's operating activities, in which the amount of cash flows from operating activities is an indicator that determines whether the operations of the company can generate sufficient cash flow to repay the loan, maintain the operating capability of the company, pay dividend to investors and create new investments without relying on external sources of funding (IAI, 1999). Therefore, by considering the cash flow of operating activities can represent the internal financial performance of the company without any influence from outside the company.

Based on the aforementioned research and theories, the authors plan to develop and perform research financial ratio through net profit margin, return on equity, debt to equity ratio, current ratio, price to book value, total asset turnover, and earning per share. Moreover, it also uses additional supporting variables that can affect investors in making decisions through operational cash flow and size of the company and its impact on stock returns to be gained by investors.

Although the research of stock returns has been widely conducted, this research is still interesting to be re-examined because the results of research are inconsistent or different. Therefore, it encourages the researcher to conduct a research return on stock return by merging and developing based on previous research. This research is based on previous research conducted by Martani et al. (2009) which examined the influence of financial ratios, 
firm size, and operating cash flow to stock returns, and research conducted by Taani (2011) which examined the influence of financial ratios, firm size and operating cash flow to earnings per share. Martani [9] studied the effects of financial ratios, firm size and cash flow on stock returns have become a reference for subsequent research including Taani (2011) by using the same independent variables as Martani et al. (2009) and Pouraghajan et al. (2013) on the Tehran Stock Exchange in Iran and Vedd et al. (2014) states in the State of California United States.

Based on the results of aforementioned research, the authors perform another research with different conditions, locations and research periods. In addition, this research tries to combine the variables found in previous research by developing a research framework using mediation variables that is expected to further strengthen the influence between exogenous and endogenous variables of this research.

Based on the above description the authors are interested to examine the variables that affect stock returns on manufacturing companies listed on the Indonesian Stock Exchange. The research problem is formulated as follows: (1) whether net profit margin, return on equity, current ratio, debt to equity ratio, total assets turnover, price to book value, firm size, and cash flow operation effect on earnings per share? (2) Whether earning per share mediates the relationship between net profit margin, return on equity, current ratio, debt to equity ratio, total assets turnover, price to book value, firm size, and cash flow operation against stock return?

The objectives in this research are (1) To examine whether net profit margin, return on equity, current ratio, debt to equity ratio, total assets turnover, price to book value, firm size, and cash flow operation effect on earnings Per share (2) The second research objective is to examine the effect of earning per share in mediating the relationship between net profit margin, return on equity, current ratio, debt to equity ratio, total assets turnover, price to book value, firm size, and cash flow operation on stock return.

\section{METHODS OF RESEARCH}

This research is a quantitative research with a framework that evaluates theories through measurement of research variables with numbers and statistical methods in performing data analysis (Indriantoro and Supomo, 2002). This emiprical research uses hypothesis to evaluate consistency of empirical findings especially related to the influence of independent variable to dependent variable (Sekaran, 2009).

The population in this research is all manufacturing companies listed on the BEI (Indonesia Stock Exchange) in 2008 - 2014. The reason for choosing the time period is that the longer the study period, it can help to increase the accuracy of the result. This research was extended until 2014 because the data is relatively new.

The sample in this research has been selected in such a way that the sample used is not biased and able to reflect the actual conditions. Sampling method that is used is purposive sampling method, which is to select the sample based on certain criteria that have been determined. These criteria include the companies are in manufacturing group and listed on the BEl during the period of observation, i.e. 2008-2014; the companies publish their audited financial statements for fiscal year 2008-2014; the companies are never delisting; the shares of these companies are actively traded during the years 2008-2014.

The data are collected based on historical records or data that already exist (Jogiyanto, 2007). The data collected in this research is an annual report of manufacturing companies listed on the BEI and related to the research variables. Based on the time dimension, the data used in this research is cross-sectional data, where the data obtained comes from a series of observations on a variable taken at one point of time.

Source of data used in this research is secondary data. Secondary data is generally a source of research data that can be obtained indirectly and without doing direct observation in the field. Secondary data can be in the form of evidence, records or historical reports of a research object that has been prepared in the archive of both published and not published data. 
This research uses ten variables and each variable has its own operational definition. The operational definition is a way of measuring these variables in order to operate (Jogiyanto, 2007). Basically the data to be used in this research can be grouped into three groups of variables, namely: independent variable i.e. net profit margin, return on equity, current ratio, and debt to equity ratio, total assets turnover, price to book value, firm size, cash flow operation. Mediation variables in this research are earning per share and stock return as the dependent variable.

This research uses ten variables and each variable uses the measurement as presented in Table 1.

Table 1 - Research Variable

\begin{tabular}{|c|c|c|}
\hline No & Point & Description \\
\hline 1 & ROE & Net Income / Total Equity \\
\hline 2 & DER & Total Liabilities / Total Equity \\
\hline 3 & NPM & Net Profit / Revenue \\
\hline 4 & CR & Current Assets / Current Liabilities \\
\hline 5 & TATO & Net Sales / Total Assets \\
\hline 6 & PBV & Stock's Market Value / Book Value \\
\hline 7 & SIZE & (Ln) Logarithm Total Assets \\
\hline 8 & CFO & (Ln) Logarithm Cash Flow Operation \\
\hline 9 & EPS & Net Income / Average Outstanding Shares \\
\hline
\end{tabular}

Sources: Research variables based on aforementioned reseraches by Martani (2009), Taani (2011), Pouraghajan et al. (2013), and Vedd et al. (2014).

Return of stock is the amount of stock return received by the shareholders. The return of stock used in this research using realized returns calculated by calculating the difference between the initial period price and the end period price of the stock. The calculation of stock returns in previous studies used the closing price during the observation period Jogiyanto (2003) with eq. (1).

$$
\mathrm{R}_{\mathrm{ti}}=\frac{\left(\mathrm{P}_{\mathrm{ti}}-\mathrm{P}_{\mathrm{ti}-1}\right)+\mathrm{D}}{\mathrm{P}_{\mathrm{ti}-1}}
$$

Where: $P_{t i}=$ Individual Share Price in Period $t ; P_{t i-1}=$ Individual Share Price in Period $t-1$; $\mathrm{D}=$ Deviden.

Hypothesis testing in this research using SEM analysis (Structural Equation Models) with Path analysys method. Path analysis method varies depending on the relationship between the model of variables studied. In this research path analysis using a mediation model with the direction of relationships between variables arranged in the same direction. Therefore, the estimation of the regression equation used for testing the hypothesis defined as:

$$
\begin{gathered}
\mathrm{EPS}_{\text {it }}=\beta 1 \mathrm{NPM} \text { it }+\beta 2 \mathrm{ROE} \text { it }+\beta 3 \text { CR it }+\beta 4 \text { DER it }+\beta_{5} \mathrm{TATO}_{\text {it }}+\beta_{6} \mathrm{PBV}_{\mathrm{it}}+\beta_{7} \mathrm{SIZE}_{\text {it }}+\beta_{8} \mathrm{CFO}_{\text {it }}+e_{1} \ldots[1] \\
\text { RETURN } N_{\mathrm{it}+1}=\beta_{9} \mathrm{EPS}_{\text {it }}+e_{2} \ldots[2]
\end{gathered}
$$

Here in after the following are the stages of testing variables that must be performed:

Descriptive statistics are statistics that is used to collect, process, present, and analyze quantitative data descriptively. Specifically, descriptive statistics are used to indicate the amount of data and show the average value, standard deviation, minimum value, and maximum value of the variables studied.

Linearity test is used to determine whether or not linear relationship between exogenous variables and endogenous variables. The test criteria states that if the probability value <level of significance (alpha $(\alpha=5 \%)$ ) then it is said that there is a linear relationship between exogenous variables and endogenous variables. If there are variables that are not linear shows the variable contains extreme data and there is imbalance to other variables, so that variable can not be analyzed and must be discarded. 
Designing structural model (inner model), design of structural model of relationship between variables on Partial Least Square (PLS) is based on the formulation of the problem or hypothesis in the research. When designing a structural model has been completed, then the design of inner model is further expressed in the form of a lane diagram. The initial stage of testing that must be done in using SmartPLS 2.0 M3 application is designing a structural model of research. After designing the structural model of the next research determine the path diagram or research direction in this research using path analysis (path analysis).

Goodness of fit Model is intended to determine the ability of endogenous variable to explain the diversity of exogenous variables, or in other words to determine the contribution of exogenous variables to endogenous variables.

Hypotesis Testing. Testing the significance of the variable directly (direct effect). Significance testing is used to test the hypothesis developed in the model that is the influence of exogenous variables on endogenous variables. Hypothesis testing in the research emerged because of the background that formed a research design and research objectives. The level of confidence used in this research is $95 \%$, therefore that for the level of precision or limit the inaccuracy of the data that can be tolerated is $(\alpha)=5 \%=0.05$ and with t-table value of 1.96 .

Indirect significance test through mediation variable (indirect effect) is performed with the intention to determine whether there is indirect influence between independent variables to the dependent variable through variables that mediate the relationship of these two variables.

Hypothesis testing of research that there are variables that mediate can be done through testing Sobel (Sobel Test). Testing Sobel, this test can be performed manually in excel work paper using Sobel Test test formula.

Sobel Test is conducted in to calculate the power of indirect effect between the independent variable (exogenous) to the dependent variable (endogen) through the variables that mediate the relationship between the two variables. The indirect effect of $X$ to $Y$ through $M$ is calculated by multiplying the path $X \rightarrow M(a)$ by the path $M \rightarrow Y(b)$ or ab. Thus the coefficient $a b=(c-c)$, where $c$ is the effect of $X$ against $Y$ without control $M$, and $c$ is the coefficient of influence $X$ against $Y$ after controlling $M$ (Ghozali, 2011).

Testing criteria is said to be significant influence if T-Statistics $\geq T$-Table 1.96. Indirect effect can be concluded after calculated using Sobel Test method. This test can be done manually in excel work paper using Sobel Test test formula.

\section{RESULTS OF STUDY}

Data are collected from all manufacturing companies listed on the Indonesia Stock Exchange in 2008-2014 obtained as many as 146 companies; furthermore, data are sampled sampling with purposive sampling method with certain criteria obtained 38 company samples.

The research was conducted for 7 years starting from 2008 to 2014. Hypothesis testing in this research used SEM (Structural Equation Models) analysis with path analisys method, where the results of the test in this research were obtained as follows:

Descriptive analysis results obtained that the highest average (Mean) is on the Return on Equity (ROE) that of 16.471 and the lowest in stock returns of 0.254 . Next standart deviation or the highest standard deviation also shows that the variable Return on Equity (ROE) of 28.364 and the lowest in stock return variable of 0.576 . The number of sample in this research is 38 go public companies listed in $\mathrm{BEI}$ and meet the criteria specified in the research, where the test of descriptive analysis is presented through Table 2.

Linearity test in this research shows that there is no variable that is not linear, thus can be stated that all relation between exogenous variable to endogenous variable is linear correlation.

After designing the structural model then the path determine diagram or research direction, which in this research using path analysis and obtained inner model. After the inner 
model and path diagram is formed and the data of each variable is processed into the research model then the next is calculating the data research results.

Table 2 - Descriptive Analysis

\begin{tabular}{lllll}
\hline No & Variable & $\mathrm{N}$ & Mean & Std.deviation \\
\hline 1 & NPM & 228 & 7.268 & 8.060 \\
2 & ROE & 228 & 16.471 & 28.364 \\
3 & CR & 228 & 2.299 & 1.740 \\
4 & DER & 228 & 1.276 & 1.546 \\
5 & TATO & 228 & 1.340 & 0.609 \\
6 & PBV & 228 & 3.947 & 7.514 \\
7 & SIZE & 228 & 15.182 & 1.560 \\
8 & CFO & 228 & 9.643 & 8.511 \\
9 & EPS & 228 & 4.352 & 2.912 \\
10 & RS & 228 & 0.254 & 0.576 \\
& Valid N (listwise) & 228 & & \\
\hline
\end{tabular}

Sources: Descriptive statistical test results using SPSS 20 of manufacturing companies listed on the Stock Exchange.

Table 3 - Linearity Testing

\begin{tabular}{lllll}
\hline No & Eksogen & Endogen & $\mathrm{F}$ & Sig. \\
\hline 1 & NPM & EPS & 213.351 & 0.000 \\
2 & ROE & EPS & 149.607 & 0.000 \\
3 & CR & EPS & 12.871 & 0.000 \\
4 & DER & EPS & 50.351 & 0.000 \\
5 & TATO & EPS & 6.122 & 0.014 \\
6 & PBV & EPS & 31.516 & 0.000 \\
7 & SIZE & EPS & 27.125 & 0.000 \\
8 & CFO & EPS & 26.976 & 0.000 \\
9 & EPS & RS & 10.709 & 0.001 \\
\hline
\end{tabular}

Sources: The results of linearity testing using SPSS 20 of manufacturing companies listed on the Stock Exchange.

The result of data processing is then used to calculate the significant influence between the variables based on the structural model design of the research. Figure 1 is the result of the design of inner model based on the research framework, for the next done data processing:

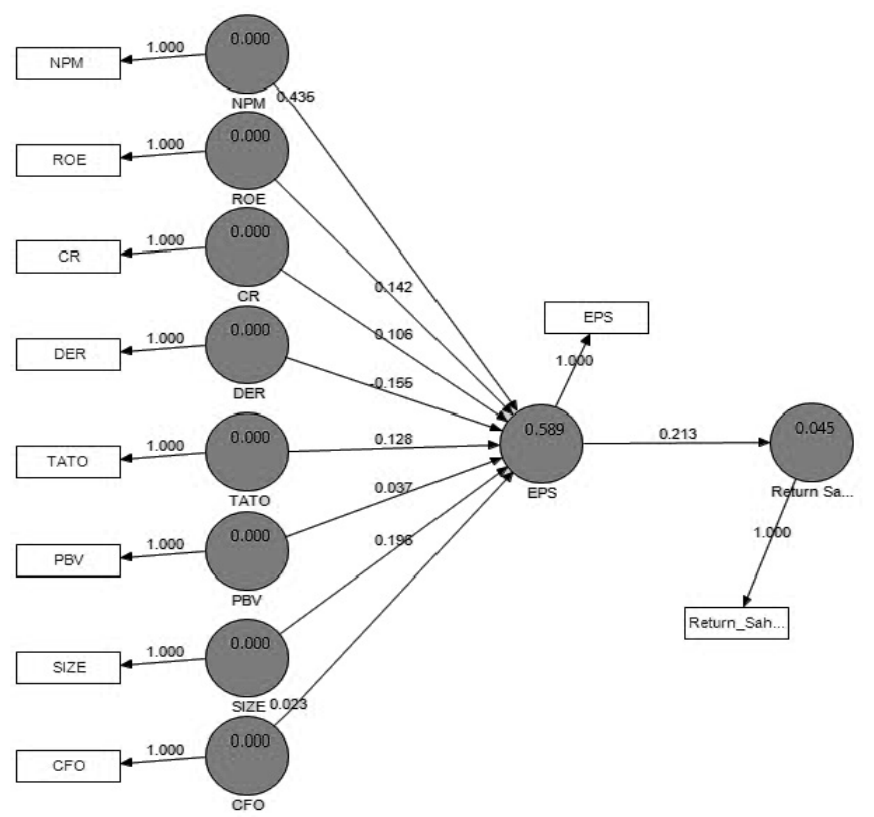

Figure 2 - Result of the Design of Inner Model 
Goodness of fit Model in PLS analysis is performed by using Q-Square predictive relevance (Q2) taken from R-Square (R2) value to dependent variable or influenced variable. R-Square (R2) variable Earning per share (EPS) is 0.589 or $58.9 \%$ and R-Square (R2) stock return variable is 0.045 or $4.5 \%$. Therefore, obtained $Q$-Square predictive relevance (Q2) is worth 0.607 or $60.7 \%$.

Table 4 - R-Square $\left(R^{2}\right)$ Calculation

\begin{tabular}{lll}
\hline No & Variable & $R^{2}$ \\
\hline 1 & Earning per share & 0.589 \\
2 & Stock return & 0.045 \\
\hline
\end{tabular}

Sources: Bootstraping data - the path coefficients result of SmartPLS 2.0 M3 of endogenous variables.

$$
\begin{gathered}
\mathrm{Q}^{2}=1-\left(1-\mathrm{R}_{1}{ }^{2}\right) \times\left(1-\mathrm{R}_{2}{ }^{2}\right) \\
\mathrm{Q}^{2}=1-(1-\text { EPS }) \times\left(1-\mathrm{RETURN}^{2}\right) \\
\mathrm{Q}^{2}=1-(1-0,589) \times(1-0,045) \\
\mathrm{Q}^{2}=0,607
\end{gathered}
$$

The results show the contribution of Net Profit Margin (NPM), Return on Equity (ROE), Current Ratio (CR), Debt to Equity Ratio (DER), Total Assets Turnover (TATO), Price to Book Value (PBV), Cash Flow Operation (CFO) and Earning Per Share (EPS) to the overall Stock Return $60.7 \%$, while the rest of $39.3 \%$ is the contribution of other variables that are not discussed in this research.

Hypothesis Testing. Direct test results (direct effect) on the 9 research variables result is 5 variables that directly influence direct (direct effect). These variables are influence of net profit margin (NPM) to earnings per share (EPS) of 3,588, the effect of debt to equity ratio (DER) to earnings per share (EPS) of -2.912, the influence of total assets turnover (TATO) to earnings per Share (EPS) of 2.540, the effect of firm size on earnings per share (EPS) of 2.773 , and the effect of earnings per share (EPS) on stock return is 3.487 . Summary of direct effects test results is presented in Table 5.

Table 5 - Direct Effect Result

\begin{tabular}{llll}
\hline No & Exogen & Endogen & T Statistics (|O/STERR $)$ \\
\hline 1 & NPM & EPS & 3.588 \\
2 & DER & EPS & -2.912 \\
3 & TATO & EPS & 2.540 \\
4 & SIZE & EPS & 2.773 \\
5 & EPS & RS & 3.487 \\
\hline
\end{tabular}

Sources: Data bootstraping - path coefficients result of SmartPLS 2.0 M3 of variable that directly affects direct (direct effect) on earnings per share in the equation of the first hypothesis.

Tests of indirect significance through the variable mediation (indirect effect) on 8 variables studied can shows that, there are 4 variables indirect effect (indirect effect) significant effect on stock return.

Table 6 - Inderect Effect Result

\begin{tabular}{lllll}
\hline No & Exogen & Mediation & Endogen & T Statistics $(|\mathrm{O} / \mathrm{STERR}|)$ \\
\hline 1 & NPM & EPS & RS & 2.500 \\
2 & DER & EPS & RS & -2.235 \\
3 & TATO & EPS & RS & 2.053 \\
4 & SIZE & EPS & RS & 2.170 \\
\hline
\end{tabular}

Sources: The indirectly significant variable uses the earning per share as the mediation variable in the second hypothesis equation using Sobel Test calculation.

These variables include earnings per share (EPS) able to mediates the relationship between net profit margin (NPM) to stock return of 2,500, earnings per share (EPS) able to mediates the relationship between debt to equity ratio (DER) to stock return of -2.235 , Earnings per share (EPS) is able to mediate the relationship between total asset turnover 
(TATO) to stock return of 2.053, and earnings per share (EPS) mediating the relationship between firm size to stock return of 2,170. Summary of indirect effect test results is shows in Table 6.

\section{DISCUSSION OF RESULTS}

This research is conducted to evaluate and analyze the influence between financial ratios, firm size and operating cash flow to stock return through earning per share in manufacturing companies in Indonesia. The test is performed to determine the direct effect of the variable financial ratios (net profit margin, return on equity, debt to equity ratio, current ratio, price to book value, total asset turnover), firm size and operating cash flow to earnings per Share. Furthermore, this research also investigates the indirect effects of variable financial ratios (net profit margin, return on equity, debt to equity ratio, current ratio, price to book value, total asset turnover), firm size and operating cash flow to stock return through Earning per share as a mediation variable. The use of financial ratios, firm size and operating cash flows that are information derived from the company's financial statements as a factor affecting stock return is an attempt to identify the signaling theory through earnings per share.

Based on the result of data analysis, it is concluded that the contribution of financial ratio variable which consist of profitability ratio through net profit margin (NPM) and return on equity (ROE), value through book value (PBV) ratio, debt ratio through debt to equity ratio $D E R)$, liquidity ratio through current ratio (CR), activity ratio through total asset turnover (TATO), and other characteristics that can also describe the company's condition through firm size (SIZE) and cash flow operation (CFO) and earnings per share (EPS) ) To the overall stock return is $60.7 \%$, while the rest of $39.3 \%$ is the contribution of other variables that are not discussed in this research.

In general, the results of this research support the theory to the effect of financial statement information on investment decisions that will affect stock prices and stock returns in efficient markets. The results of the research have found that financial ratios measured through net profit margin (NPM), debt to equity ratio (DER), total asset turnover (TATO), firm size (direct effect) influence earnings per share EPS) calculated through the company's earnings. While Stock Return is directly influenced by earnings per share (EPS).

The indirect effect in this research uses path analysis which can be concluded that the stock return is indirectly influenced by net profit margin (NPM), debt to equity ratio (DER), total assets turnover (TATO) And firm size (SIZE) through earning per share (EPS) as a mediation variable.

The results of this research explain there are phenomena associated with signaling theory. This can be proved by the influence of firm size (SIZE), net profit margin (NPM), debt to equity ratio (DER), total assets turnover (TATO), and earnings per share (EPS) to stock return. Financial information into investor consideration in evaluating company performance and the company's going concern.

The effect of earning per share (EPS) as a functioning mediating variable strengthens the influence between exogenous and endogenous variables capable of being shown in this research. This is indicated by the significance of variables that significantly affect earnings per share (EPS) also have a significant effect on stock returns. These results are able to explain that earnings per share (EPS) will provide additional financial information that will be a consideration for investors in making a profit in investing in efficient markets.

\section{CONCLUSION}

There are limitations in this research that can provide insight for further research direction i.e. (1) apart from the variables that are used to evaluate stock returns and earnings per share which tend to be subjective, there might be missing variable in which give greater influence on stock return variable. (2) Only specific population that is used i.e. manufacturing companies listed in Indonesia Stock Exchange (BEI), therefore it may not be able to describe 
the effect of these variables on stock returns. (3) There are other factors that are not listed in this research affecting stock return that can influence investors' decisions in investing.

\section{ACKNOWLEDGEMENTS}

Thank you to Allah SWT who has provided many sustenance and guidance. We also thank God our Prophet Muhammad, who has guided us to the blessings of faith and Islam. To both of my parents who have always been eager for me to complete this research, and my beloved wife who patiently helped me and was willing to become partners in completing this paper. I would also like to thank the counselors who have been patiently and kindly so that the research can be resolved.

\section{REFERENCES}

1. Alexander, G. 1993. "Fundamentals of Dividen" IIAER: August 2003, Vol. 9, No. 3

2. Bhattacharya, S. 1979. Imperfect Information, Dividend Policy, and The Bird in the Hand Fallacy. The Bell Journal of Economics, 10(1), Pages:259-270.

3. Daniati, N. and Suhairi. 2006. "Pengaruh Kandungan Informasi Komponen Laporan Arus Kas, Laba Kotor, dan Size Perusahaan terhadap Expected Return Saham (survey pada industri textile dan automotive yang terdaftar di BEJ)". Padang: Simposium Nasional Akuntansi 9: August, 23-26

4. Ghozali, I. 2011. "Aplikasi Analisis Multivariate Dengan Program SPSS".Semarang: Badan Penerbit Universitas Diponegoro.

5. Huda, N. and Nasution, M. E. (2008). Investasi pada pasar modal syariah. Cetakan ke-2. Jakarta: Kencana.

6. IAI. 1999. Standar Akuntansi Keuangan Jakarta: Salemba Empat.

7. Indriantoro, N. and Supomo, B. 2002. Metedologi Penelitian Bisnis. Yogyakarta: Edisi Pertama. Penerbit BPFE.

8. Jogiyanto, H. 2003. Teori Potofolio dan Analisis Investasi. Edisi Ketiga. Yogyakarta.

9. Jogiyanto, H. 2007. Model Kesuksesan Sistem Teknologi Informasi.Yogyakarta: Andi

10. Martani, D., Mulyono, and Khairurizka, R. 2009. "The Effect of Financial Ratio, Firm Size, and Cash Flow from Operating Activities in the Interim Report to The Stock Return". USA: Chinese Business Review. ISSN 1537-1506, Vol.8, No.6: 44-55 (Serial No.72).

11. Panjaitan, Y. 2004. "Analisis Harga Saham, Ukuran Perusahaan, dan Risiko terhadap Return yang Diharapkan Investor Pada Perusahaan-Perusahaan Saham Aktif". Jurnal Akuntansi, Auditing dan Keuangan. Vol.1 No.1, April 2004

12. Pouraghajan, A., Elham M., Seyedah, M., Milad, E., Bahareh, E. 2013. "Investigation the Effect of Financial Ratio, Operating Cash Flows and Firm Size on Earning Per Share: Evidence from the Tehran Stock Exchange". International Research Journal of Applied and Basic Science. Vol.4 (5). ISSN 2251-838X. Pages: 1026-1033.

13. Riegel, J. J. 2013. Stock for the Long Run 5/E: The Definitive Guide to Financial Market Returns and Long-Term Investment Startegies. Fifth Edition. McGraw-Hill: 448

14. Rozeff, M. 1982. "Growth, Beta and Agency Cost as Determinants of Dividend Payout Ratios". Journal of Financial Research, Fall, 249-259.

15. Sekaran, U. 2009. Research Methods For Business Metodologi Penelitian Untuk Bisinis Buku I Edisi 4. Penerbit Salemba Empat. Jakarta.

16. Taani, K. 2011. "The Effect of Financial Ratio, Firm Size, and Cash Flow from Operating Activities on Earning per share: (an applied study on jordanian industrial sector)". Jordania: International Journal of Social Science and Humanity Studies. Vol.3, No.1: 197205, ISSN 1309-8063.

17. Van Horne, C.J. 2005. Prinsip-prinsip Manajemen Keuangan. Buku Satu. Edisi Kedua Belas. Alih Bahasa oleh Dewi Fitriasari dan Deny Arnos Kwary. Jakarta: Salemba Empat.

18. Vedd, R., Paul L., \& Nataliya Y. 2014. "Multivariables Determining Earnings per Share within the U.S. Medical Laboratories \& Research Industry". Laboratories and Research Industry: Archives of Business Research Vol.2, No.4: August 30,2014. Pages: 150 - 160. 